\title{
Субпериостален екстракраниален абсцес и зигоматит
}

\author{
Пламен Костов Недев \\ Клиника по УНГ болести УМБАЛ „Св. Марина” гр. Варна
}

\begin{abstract}
The incidences of extracranial and intracranial complications have decreased significantly in the past 10 years. The most frequent cause for otogenic extracranial complications are cholesteatomas. In this article we present a case of 73 years old patient with rare extracranial complication due to chronic otitis media. The inflamation spreads through anterior air cells to the zygomatic cells leading to a fistula formation in the zygomatic bone and engaging the temporal muscle.
\end{abstract}

Keywords: Otogenic extratracranial complications, otitis media, zygomatitis

\section{Резюме}

Случаите на екстра- и интракраниални компликации намаляват през последните 10 години. Най-честата причина за тези усложнения е холестеатомът. В статията се представя случай на 73-годишен пациент с рядко екстракраниално усложнение вследствие на хроничен отит. Възпалителният процес се разпросранява през предните клетки към зигоматичните клетки и кост, като образува фистула и ангажира темпоралния мускул.

Ключови думи: отогенни екстракраниални усложнения, среден отит, зигоматит

\section{Увод}

Отогенните усложнения могат да бъдат класифицирани в две големи групи: интракраниални и екстракраниални. Интракраниалните включват менингит, менингоенцефалит, екстрадурален абцес, мозъчен абцес, тромбоза на сигмуиден синус и др. Екстракраниалните усложнения включват субпериостален абцес, лабиринтит, мастоидит, периферна парализа на лицевия нерв и др. Според статистическите проучвания [1] интракраниалните компликации се срещат близо два пъти по-рядко отколкото екстракраниалните.

По данни от литературния обзор [2-6] смъртността от отогенни усложнения варира от $8-26,3 \%$, а трайните увреждания от 12,2 - 13,6\%. Етиологията на отогенните усложнения са различни гноеродни грам-положителни и грам-отрицателни, анаеробни микроорганизми, като най-често се касае за смесена микрофлоpa (напр. Streptococcus, Pseudomonas, Staphylococcus aureus, Citrobacter, Enterococcus, Klebsiella pneumoniae, Diphtheroides) [7]

\section{Представяне на случай}

Касае се за случай на 73-годишен мъж, постьпил в клиниката в тежко септично състояние, със силна болка в лявата половина на главата. (фигура $1,2,3$ ) Обективно се наблюдава принудително положение на главата и невъзможност за движение на врата (torticollis), изместване на ушната мида надолу и напред, значителен оток на меките тъкани ретроаурикуларно, достигащ напред до орбитата, флуктуация и хиперемия на кожата. Установява се изпълнен с холестеатом- 


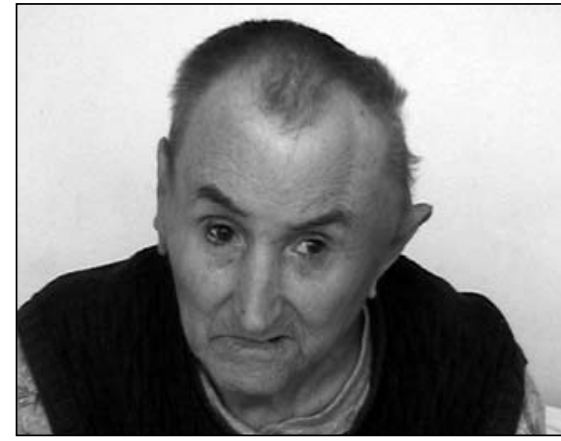

Фиг. 1. Фронтален изглед на паци- Фие. 2. Същият пациент, ретроент с екстракраниално усложнение аурикуларен изглед

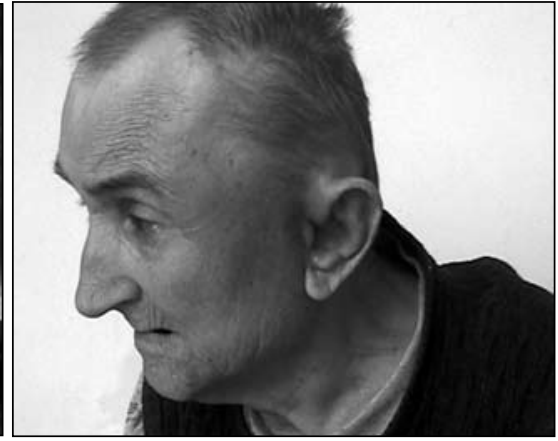

Фие. 3. Същият пациент, профил ни маси външен слухов проход, гноен ексудат с неприятна миризма. На КАТ се констатира ерозия, характерна за хроничен отит и значително количество ексудат между черепни кости и меки тъкани, вкл. лявата орбитата. (фигура 4)
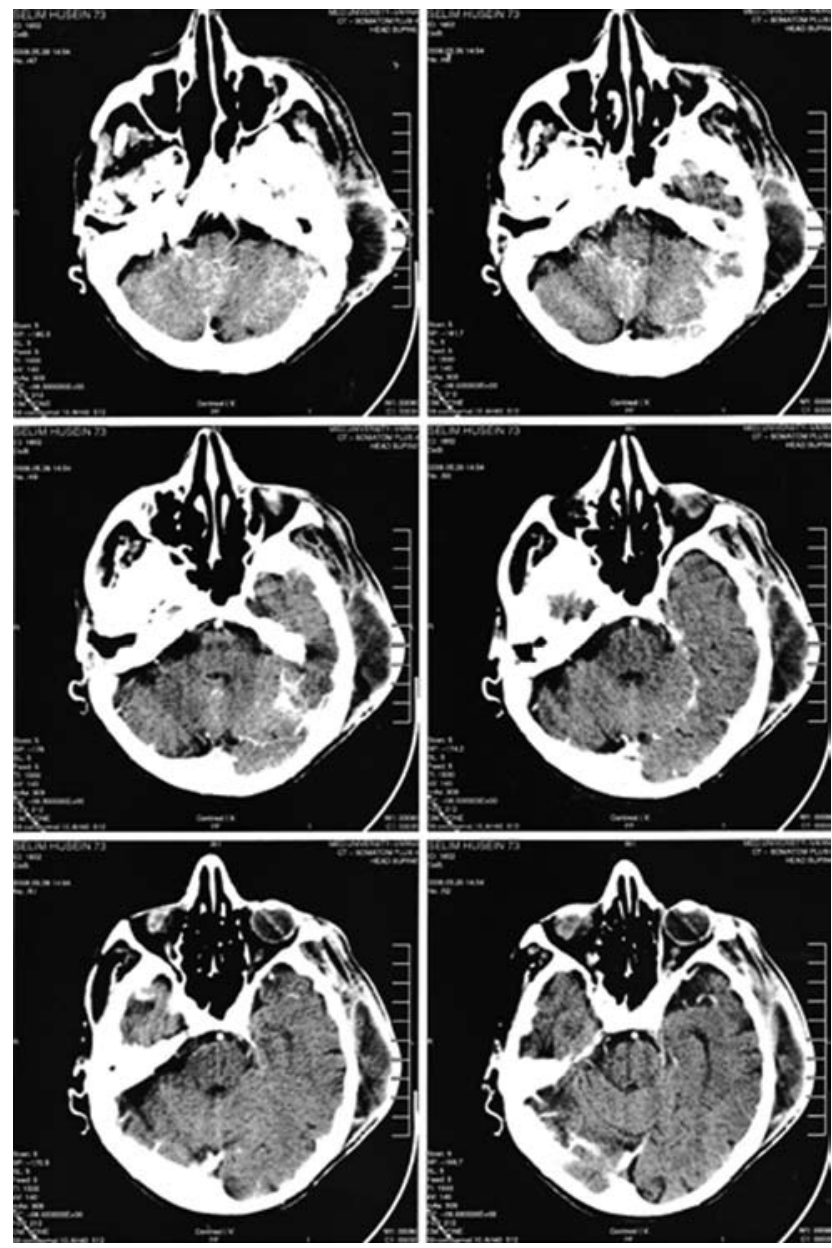

Фиг. 4. КАТ на екстракраниалното усложнение

Проведе се оперативно лечение с премахване на холестеатом, който беше създал голяма кухина, съответстваща на радикална трепанация. от пространството между кожа и черепни кости се дренира 150-200 ml гноен ексудат. Инфламаторният процес беше ангажирал зигоматичните клетки, темпоралния мускул и шийните мускули. Извърши се радикална мастоидектомия и ревизия на зигоматичните клетки. Липсваха данни за навлизане на инфекцията в ендокраниума. Остави се широко отворена оперативна кухина с дренаж, заздравяваща per secundam. Приложиха се цефазолин, метронидазол и гентамицин. Следоперативният период протече гладко с пълно възстановяване на пациента.

\section{Дискусия}

Предразполагащите фактори за инракраниално усложнение са локални (топографско-анатомичното положение на ухото, многото съдови връзки с ендокраниума, тънките костни структури и близостта на мозъчното съдържимо) и общи (намаление на съпротивителните сили на макроорганизма, незряла имунна система, придобита или вродена имунна недостатъчност, сидеропения, ексудативна диатеза, чести респираторни инфекции, алергия, тежки хронични или прекарани заболявания, водещи до срив в имунната система). От страна на микроорганизмите - резистентна или силно вирулентна микрофлора и др. Патогенезата и патологоанатомията на отогенните усложнения се свързват със следното: инфекцията преминава към ендокраниума, вследствие хроничен обострен отит - епитимпанит (холестеатом), мастоидит. Макар и по-рядко, но е възможно и от остър отит. Отогенните усложнения се срешат по-често при мъже, отколкото при жени

Пътищата на проникване на инфекцията са:

Преформирани пътища (т.е. вече съществуващи):

- през горната или долната стена на тьпанчевата кухина;

- кръвен път;

- клетките на мастоидната и темпоралната кост;

- през лабиринта и вътрешния слухов проход. 
Новосъздадени пьтища - след разрушаване на костните структури.

В миналото радикалната мастоидектомия е била единствена алтернатива за лечение на интракраниалните усложнения, но с навлизането на все по-мощни антибиотици, индикациите и възможностите за консервативно лечение са значително разширени. Най-често прилагани са цефалоспорини, аминогликозиди, метронидазол и хлорамфеникол. Тъй като причинителите на хроничните отити и техните усложнения са твърде разнообразни, използваните антибиотици имат спорно, а понякога и конфликтно един спрямо друг въздействие. В някои случаи прилагането на антибиотично лечение воалира инфекцията. Поради тази причина

\section{Литература:}

1. Kangsanarak J, Fooanant S, Ruckphaopunt K, Navacharoen N, Teotrakul S. Extracranial and intracranial complications of suppurative otitis media: report of 102 cases. J Laryngol Otol 1993; 107: 999-1004.

2. Park H, Jang H, Shim D, Shin H, Ahn J, Shin J, Surgical management of acute mastoiditis with epidural abscess. Acta Oto-Laryngologica [Acta Otolaryngol], $2006 \mathrm{Jul}$; Vol. 126 (7), 782-4

3. Ricardo Bento, MD; Rubens de Brito, MD; Guilherme Carvalhal Ribas, MD "Surgical management of intracranial complications of otogenic infection" ENT-Ear, Nose \& Throat Journal, January 2006

4. Kaftan H, Draf W. Intracranial otogenic complications: in spite of therapeutic progress still a serious problem. Laryngorhinootologie 2000; 79: 609-15 (in German). като принцип в лечението на интракраниалните усложнения се възприема навременното хирургично саниране.

\section{Заключение}

През последните години се наблюдава намаление на честотата на отогенните усложнения, за сметка на „запуснатост” и тежест на заболяването и поради това представляват сериозен клиничен проблем. Холестеатомът и гранулиращият остеит са чести находки в тези случаи. Оперативното лечение е наложително и би следвало да включва максимален радикализъм.

5. Samuel J, Fernandes CMC, Steinberg JL. Intracranial otogenic complications: a persistent problem. Laryngoscope 1986; 96: 272-8.

6. Kuczkowski, J., Narozny, W., Stankiewicz, C. Mikaszewski, B. and Izycka-Swieszewska, E. Zygomatic abscess with temporal myositis - a rare extracranial complication of acute otitis media, International Journal of Pediatric Otorhinolaringology, 2005, V. 69, Issue 4, pp. 555-559

7. Migirov, L. Duvdevani, S. and Kronenberg, J. Otogenic intracranial complications: A review of 28 cases Acta Oto-Laryngologica, 2005; 125: pp. 819-822

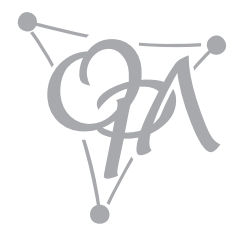

